\title{
INTERVJUU KEELEANDMETE KOGUMISE MEETODINA
}

\section{Kristiina Praakli}

\begin{abstract}
Ülevaade. Keelekasutuse uuringutes tuntakse erinevaid ainestikutüüpe, nagu intervjuu, argivestlused, osalusvaatlustel põhinevad ainestikud, päevikumärkmed, ankeetküsitlused, eksperimendid, kirjalikud tekstid, autobiograafiad, helimaterjalid, raadio- ja telesaated, e-kirjad jne. Tõenäoliselt nõustub iga empiirilise ainestikuga töötav uurija väitega, et ideaalset keeleandmete kogumise meetodit ei ole olemas. Artiklis käsitletakse intervjueerimise ja intervjuuainestike spetsiifikat keeleuuringute eesmärkidest ja vajadustest lähtuvalt. Vaadeldakse selliseid empiiriliste uuringute põhiprobleeme nagu vaatleja paradoks, intervjueerija ja intervjueeritava suhe ja koostöö ning nende vastastikune mõjutamine. Nimetatud aspektid on tegurid, millest oleneb keeleandmete kogumise edukus.
\end{abstract}

Võtmesõnad: suuline kõne, keeleainestikud, keeleline käitumine, sotsiolingvistika, empiiriline ainestik, eesti keel

\section{Intervjuu mõiste ning intervjuude põhitūūbid}

Intervjuu tähendab ühiselt konstrueeritud vestlust intervjueerija ja intervjueeritava vahel (Codó 2008: 163). Intervjuumeetod on kiire, süstemaatiline ning paindlik suuliste keeleandmete kogumise meetod, mis võimaldab hankida detailset teavet "siin ja praegu". Sirkka Hirsjärvi, Pirkko Remes ja Paula Sajavaara (2005: 192) nimetavad intervjuuainestike eelistena paindlikkust ning võimalust andmekogumist vastavalt olukorrale ja vastajale reguleerida. Eva Codó (2008: 159) toob intervjuumeetodi puhul välja kaks eelist: esiteks, intervjuud on lihtsam ette valmistada selleks valitud keelejuhtidega kui hankida luba loomuliku suulise kõne lindistuste tegemiseks; teiseks, erinevalt loomulikust sotsiaalsest suhtlusest võimaldab meetod kontrollitumat keskkonda teatud keelevormide kogumiseks. See tähendab, et uurijal on võimalik intervjuu vajalikus suunas ette valmistada ning viia vestlus teadlikult nendele teemale, mis suurendaksid ühe või teise teema kaudu uuritavate 
keelevormide sagedamat kasutust. Keeleandmete hankimine toimub justkui kaudselt: intervjueerija vestleb intervjueeritavaga erinevatel teemadel, pidades silmas, et vestlusteemad võimaldaksid soovitud keeleainestikku hankida. Samas annab igasugune teave kogukonna normide ja üldise sotsiaalse ja kultuurilise tausta kohta ainestikule lisaväärtust (Milroy, Gordon 2003). Intervjuu on ühtlasi hea meetod uuritavate "maailma pääsemiseks" (Lehtonen 2004: 8).

Sotsioloogia ja sotsiolingvistika tunnevad erinevaid intervjuutüüpe: avatud intervjuu (ingl open-ended interview), teemaintervjuu (non-directive interview; focused interview), struktureerimata / poolstruktureeritud intervjuu (non-structured, semi-structured interview), süvaintervjuu (in-depth interview) jne. Järgnevas ülevaates esitatakse Eskola, Suoranta põhjal (2003: 86) intervjuutüüpide tähtsaimad tunnusjooned. Struktureeritud intervjuus on küsimuste formuleerimine ja nende esitamise järjekord kõikidele küsitletavatele alati ühesugune. Teine oluline tunnusjoon on intervjueeritavale vastusevariantide nimetamine. Pakutud variantide hulgast palutakse valida kõige sobivam. Struktureeritud intervjuud on võrreldud juhendatud ankeetküsitluste täitmisega. Poolstruktureeritud intervjuu erineb struktureeritud intervjuust selle poolest, et kuigi küsimused on kõikidele intervjueeritavatele ühesugused, ei anta küsitletavatele vastusevariante, intervjueeritav tohib vastata oma sõnadega. Teemaintervjuus määratakse eelnevalt kindlaks teemavaldkonnad, millest intervjueeritavaga vesteldakse. Puudub struktureeritud intervjuule tüüpiline küsimuste täpne formuleering ning järjekord. Intervjueerija peab tagama selle, et kõik intervjuuks valitud teemavaldkonnad oleksid käsitletud. Intervjueerija ei kasuta eelnevalt kindlaks määratud küsimusi. Avatud intervjuu on lähedane tavalisele vestlusele. Intervjueerija ja intervjueeritav vestlevad teatud teemal, kuid kõikide intervjueeritavatega ei käsitleta samu teemavaldkondi (Eskola, Suoranta 2003: 86).

Sotsiolingvistilised intervjuud on üldjuhul vähem struktureeritud ning paindlikumad (lähemalt Milroy, Gordon 2003: 57). Lawrence Neuman (2003: 391) esitab erinevatele uurijatele tuginedes prototüüpse survey-tüüpi intervjuu (küsitlus) ning väliintervjuu (ingl field interview) võrdluse. Väliintervjuusid, mis on ülesehituselt poolstruktureeritud, mittedirektiivsed või süvaintervjuud, markeerivad järgmised tunnusjooned:

1) intervjuu algus ja lõpp ei ole selged, intervjuud on võimalik ka hiljem jätkata;

2) küsimused ja küsimuste esitamise järjekord kohandatakse vastavalt keelejuhtidele ja situatsioonidele;

3) intervjueerija näitab üles huvi intervjueeritava vastuste vastu, julgustades detailide lisamist;

4) meenutab sõbralikku mõttevahetust, kuid sisaldab rohkem intervjuu küsimusi;

5) intervjuusse võib olla põimitud teemaväliseid nalju, kõrvalmärkusi, lugusid jne, mis samuti lindistatakse;

6) intervjueerija ja intervjueeritav kontrollivad koos intervjuu tempot ja suunda;

7) vastuste interpreteerimiseks on oluline intervjuu sotsiaalne kontekst ehk toimumiskoht, osalejad jne;

8) intervjueerija kohandab ennast rääkijate normide ja keelekasutusega. 
Sotsiolingvistika kasutab keeleainestike kogumisel üldjuhul teemaintervjuusid. Uurija, kes on seadnud eesmärgiks koguda keeleainestik intervjueerimise teel, langetab eri intervjuu tüüpide vahel valides otsuse niisuguse intervjuutüübi kasuks, mis oleks struktuurilt lähedane argivestlusele, kuid mis võimaldaks koguda vajaliku mahu ja kvaliteediga keeleainestikku. Keeleuurija esmane huvi keeleainestike kogumisel lasub indiviidi või rühma keelekasutuse ning keelelise käitumise võimalikult autentsel salvestamisel, seetõttu rakendatakse teemaintervjuusid neid kõige sagedamini.

Ükski sotsiolingvistiline intervjuu ei kuulu kunagi ainult ühte kategooriasse, sest uurija vajab vähemalt kahte tüüpi andmeid: esiteks sotsiobiograafilisi andmeid intervjueeritava, teiseks andmeid keelekasutuse kohta. Uuritavate sotsiodemograafilise profiili kaardistamine eeldab vähemalt intervjuu algetapis uurija liikumist struktureeritud või poolstruktureeritud intervjuutüübi tasandil, seejärel toimub üleminek teemaintervjuule:

(1) KP: Nii. Esimesed on siis taustaküsimused. Kui kaua sa oled elanud Soomes?

INF: Neli aastat.

KP: Ja oled sa elanud kogu aeg samas kohas Soomes?

INF: Jah.

KP: Kogu aeg Tamperes?

INF: Jah.

KP: Mhmh. Ja Eestis elasid sa?

INF: Tallinnas.

KP: Kes on sinu pereliikmed?

INF: Mees ja kolmeaastane laps.

KP: Ja abikaasa on

INF: soomlane.

(näide autori erakogust)

Taustaküsimustele vastamine on läbi viidud intervjuu vormis. Autori varasemale kogemusele tuginevalt suurendab ankeetküsimustike kasutamine ametlikkust, mistõttu on nendest teadlikult loobutud. Enne küsimustele vastama asumist oli keelejuhil võimalik otsustada, kas ja kui põhjalikult ta taustaküsimustele vastata soovib.

Intervjuu tüüpide piirid ning üleminekud ühelt tüübilt teisele ei ole rangelt määratletud, oluline on, et teema ning küsitlusviisi muutumine ei mõjutaks intervjuusituatsiooni, edasist suhtlust ning vestlejatevahelist koostööd halvavalt. Sõltuvalt intervjueerija kogemusest võimaldavad teemaintervjuud vähendada märgatavalt intervjuude formaalsusastet ning oskusliku küsitleja puhul ei pruugi intervjuu tavavestlusest üldjoontes erinedagi.

Intervjuu ametlikkuse vähendamiseks esitatakse küsimused võimalikult vabas vormis. Küsimuste esitamise järjekord varieerub sõltuvalt kontakti saavutamisest keelejuhiga ning intervjuu alguses valitsenud vestlussituatsioonist. Intervjuu toimub sina-vormis. Küsimusi esitades on välditud terminite ja erialasõnavara kasutamist. Tüüpilist teemaintervjuud, mille eesmärk on koguda nii keeleandmeid kui ka taustateavet Soome eestlaste kakskeelsuse kohta, kirjeldab näide (2), milles soomemõjuline fraas on esitatud paksus kirjas. 
(2) KP: Kuidas sa iseloomustaksid nimodi üldiselt eesti keele kasutamist Soomes?

INF: Ma arvan, et et on ülekaalus on see, et räägitakse nii väljaspool kui ka kodus soome keelt.

KP: Soome keelt ikkagi? Miks?

INF: Sellepärast, et nende laste pealt, keda ma seal lasteringis ja nüüd ka nüüd ka seal esimeses klassis ma olen õpetanud, ma olen märganud, et nad ei saa arugi eesti keelest, et sellisel juhul on ka küsimus sellest, et seda ei ole lihtsalt kuuldudki, sest laps võib küll otsustada, et ta ei räägi ühte keelt, aga aru saab ta ikkagi.

KP: Mis sa arvad, mis selle taga võiks olla?

INF: Tahe samastuda siia ühiskonda, sest ((taustal lapse kilked)) väliselt on see ju tege: tegelikult lihtne. Et kui me väliselt oleme nii sarnased, siis ainult see keel ja me olemegi soomlased, kui ainult seda kasutame.

(näide autori erakogust)

\section{Intervjuumeetodi probleemid}

Hoolimata eelpool nimetatud plussidest ei ole intervjuu kindlasti ideaalne suulise kõne kogumise viis ja võimalus. Intervjuu puhul on üldiselt tegemist suhteliselt ametliku vestlusega, mis mõjutab lindistuse läbiviimist, intervjueeritava käitumist ja keelekasutust. Intervjueerimisega kaasneb probleeme, mida ainestiku kogumisel ja hilisemas keeleanalüüsis kindlasti arvesse võtta tuleb.

Intervjuuainestikke on kritiseerinud paljud keeleteadlased (nt Labov 1972: 209, Schlobinski 1996: 46, Sarhimaa 1999: 76, Milroy, Gordon 2003: 57-60, Lehtonen 2004: 8, Lappalainen 2004: 16).

\subsection{Intervjuu vs. argivestlus}

Argivestluse eeliseks on loomulikum ja mitmekülgsem keeleainestik ning suurem tõenäosus koguda keelematerjali eri kohtades ja situatsioonides. Lesley Milroy ja Matthew Gordon nimetavad intervjuu ning argivestluse peamise erinevusena paarisinteraktsiooni (ingl dyadic interaction), mis leiab aset tundmatute vestluspartnerite vahel (2003: 61-62). Intervjuud iseloomustavad järgmised omadused: 1) intervjuu on eelnevalt kavandatud; 2) intervjuu algatab ja intervjuud juhib intervjueerija; 3 ) intervjueerijal tuleb tihtipeale intervjueeritavat motiveerida ning hoida vestlust üleval; 4) intervjueerija tunneb oma rolli, mida intervjueeritav alles õpib; 5) intervjueeritaval tuleb usaldada intervjueerijat, et tema räägitud juttu usalduslikult käsitletaks (Hirsjärvi, Hurme 1980: 41, viidatud Eskola, Suoranta 2003: 85 järgi).

Liina Lindström esitab oma artiklis (2001: 213-218) Tiit Hennoste kriteeriumidele tuginevalt intervjuude (L. Lindströmil murdetekstid) ning argivestluse struktuuri võrdluse. T. Hennoste nimetab argivestlust spontaanseks, sundimatuks dialoogiks, milles osaleja põhieesmärk on vestluses osalemine; vestluste infoväärtus on tüüpiliselt madal, sisu on üldistatud, afektiivne ja interaktsionaalne (pikemalt Lindström 2000: 265). Tüüpilises argivestlustes vestlevad head tuttavad informaal- 
sel territooriumil ning suhtluse eesmärk on suhtlus ise. Puudub kindel rollijaotus, suhtlejate rollid võivad vestluse käigus muutuda, vooruvahetus on vaba (Lindström 2001: 214). Ametlike vestluste kriteeriumidele vastavates murdekorpuse tekstides kõnelevad omavahel võõrad (või peaaegu võõrad) inimesed, kelle rollid on selgelt jagunenud ega muutu suhtluse käigus: küsitleja küsibja keelejuht vastab. Suhtlus toimub tavaliselt ühe osapoole jaoks tuttaval territooriumil (Lindström 2001: 214).

Vaatamata intervjuude eritasemelistele formaalsusastmetele ei ole probleemid välistatud ka teiste meetodite puhul. Näiteks argivestlustes ja osalusvaatlustes ei suuda uurija korraga jälgida kõikide kõnelejate tegevust ning keelelist käitumist; päevikumärkmete abil ei ole võimalik koguda suurt hulka keelematerjali (salaja tehtud lindistused on lubamatud), rühmalindistuste puhul võib uurija kaotada kontrolli lindistusolukorra üle ning tekib küsimus, kas igalt rääkijalt on piisavalt kõnet lindistatud (vt ka Milroy, Gordon 2003: 70).

\subsection{Vaatleja paradoks}

Uurimisprotsess on erinevate kohtumiste sari, mis mõjutab ühel või teisel viisil kõiki osapooli (Vuorinen 2001: 243). Uurija mõju ei ole võimalik vältida ka kõige põhjalikumalt ette valmistatud keeleainestiku kogumises. Uurija mõjutab ainestiku kujunemist ainuüksi sellega, et ta on sunnitud tahes-tahtmata intervjuu käiku sekkuma, esitama intervjueeritavale suunavaid ja täpsustavaid küsimusi, võibolla ka ebameeldivaid küsimusi. Annamaria Marttila (2007) rõhutab, et uurija ja keelejuhi vahelise koostöö tulemus on tehislikult uurimuse jaoks loodud jutustus, mitte loomulik vestlus.

Paljud rääkijad muudavad oma tavalist käitumist olukorras, kui nendega vestleb ja nende kõnet lindistab tundmatu uurija. William Labov (1972: 61) on seda nimetanud vaatleja paradoksiks (ingl Observer's Paradox), mille all ta peab silmas loomuliku kõne avaldumise probleeme intervjuu situatsioonis, kui uurija eesmärk on uuritava tegelike keelekasutusmustrite analüüsimine. Sotsiolingvistiliste intervjuude põhitingimus on, et kogutav ainestik peab olema spontaanse kõnega nii sarnane kui võimalik. Seetõttu on oluline luua keelejuhtidega usalduslik suhe, et nad tunneksid ennast uurijaga rääkides mugavalt ning keskenduksid vähem oma kõne kontrollimisele (Codó 2008: 160). W. Labovi soovituse järgi peab intervjueerijal olema õppija ning madalamat autoriteeti omava inimese positsioon kui inimesel, kellega ta räägib (Milroy, Gordon 2003: 62). Kuigi uurija ülesanne on panna intervjueeritav tundma ennast lindistussituatsioonis vabalt, jääb intervjueerimise teel kogutud "puhas" keel uurija jõupingutustest hoolimata alati mingil määral "ebapuhtaks", kuna vestlused lindistatakse ning diktofoni juuresolek muudab vestlussituatsiooni ebaharilikuks (Nuolijärvi 1986: 35). Mai Loog rõhutab oma uurimuse ning ainestiku kogumise protsessi näitel, et lindistusolukorra pitser jääb kogu ainestikule: kõik tulemused kajastavad keelt (Loogi uurimuses noorte kõnekeelt), mida räägiti just sellistel ja sellistel tingimustel, just sellises olukorras, just sel väljatöötatud viisil ning sellel valitud teemal (Loog 1992: 32). Ideaalis peaks vestlust lindistav diktofon või filmiv videokaamera olema kui mööbliese, mille olemasolu jääb märkamatuks nii intervjueeritavale kui intervjueerijale.

Samas on intervjuude puhul tegemist kompaktse materjaliga, mis võimaldab kogutud ainestikku ja saadud tulemusi teiste intervjueerimise teel kogutud aines- 
tikega võrrelda. Oluline on ka kontekst ja vestlustingimused. Kõik keelejuhid (ja ka intervjueerija ise) on keeleainestiku kogumises ühesugustes tingimustes: suhteliselt tundmatu vestluspartner ja keelejuhid; kindlad vestlusteemad; intervjueerija kohustus küsida ning keelejuhtide kohustus vastata ning intervjuu lindistamine.

\section{Suulise keeleainestiku kogumise puudused}

Mis tahes suulise keeleainestiku kogumisel tuleb arvestada sellega, et kõik keelejooned ei pruugi intervjuu käigus ilmneda. Eri keelejooned avalduvad erineval määral, rääkija võib ka teadlikult keelekasutust muuta ning uurimiseesmärki teades vältida uuritavate keelejoonte kasutamist (Riionheimo 2007: 37, Kunnas 2007: 33, Halmari 1997: 22). Näiteks võib kakskeelne keelekasutaja vältida tema keelekasutuses muidu ootuspäraste võõrkoodi (L2) elementide või struktuurijoonte kasutamist, seetõttu ei pruugi intervjuu situatsioon peegeldada kakskeelse kõne avaldumisvorme niisugusel kujul, nagu need muudes situatsioonides ilmneda võivad (lähemalt Riionheimo 2007: 37). Näiteks on koodivahetus pigem rühmasisene keelelise käitumise ilming, millega keeleainestiku kogumisel kindlasti arvestada tuleb (Halmari 1997: 22). Samas on esitatud ka vastupidiseid seisukohti. Kuigi formaalsetes situatsioonides suureneb kirjakeele kasutamine, ei ole Matti Suojaneni hinnangul kõik keelejooned inimese pideva kontrolli all, samuti väheneb intervjuu jooksul kontroll keelekasutuse üle (1982: 16-17).

Sotsiolingvistid on välja töötanud uurija mõju ületamiseks või vähendamiseks ja keelejuhtide argikeelekasutuse julgustamiseks mitmeid tehnikaid (nt rühmaintervjuude läbiviimine, intervjuu struktuuri muutmine; vestlusteemade muutmine jne) (Milroy, Gordon 2003: 49, Labov 1972: 61, Sarhimaa 1999: 78, Wardhaugh 2002: 151). Mõned uurijad on seisukohal, et kui keelejuhid on intervjuusse emotsionaalselt kaasatud (on põnevil, vihased, hirmunud), keskenduvad nad rohkem sellele, mida öelda, mitte sellele, kuidas öelda (Milroy, Gordon 2003: 65). Siinkohal on ilmselt tuntuimad W. Labovi (1972: 209-210) soovitused kasutada intervjueerimisel emotsionaalseid reaktsioone tekitavaid küsimusi ja teemasid, mis juhivad keeljuhi tähelepanu keelekasutuselt kõrvale. W. Labov palus intervjueeritavatel kirjeldada ohtlikke situatsioone nende elus (W. Labov: have you ever been in a situation where you were in serious danger or being killed?). Samas ei pruugi need teemad kõikidele keelejuhtidele sobida (Milroy, Gordon 2003: 61). W. Labovi intervjuutehnilisi soovitusi on järginud näiteks Anneli Sarhimaa (1999).

Intervjuumeetodi valiku puhul tuleb kõigepealt lähtuda sellest, kas uurimus on kvantitatiivne või kvalitatiivne. Mitmete uurijate hinnangul sobibki intervjuu eelkõige sageli esinevate keelejoonte (nt fonoloogiliste ja morfoloogiliste) kogumiseks (Kunnas 2007: 33 ja sealsed viited). Intervjuud on levinud ennekõike kvantitatiivsetes variaablusuuringutes, vähemal määral kasutatakse intervjuuainestikke ka kvalitatiivsetes uurimustes.

Uurimisainestike erinevust kirjeldavad allpool esitatud näited (3) ja (4). Esimene näide (3) demonstreerib kvalitatiivse, teine (4) kvantitatiivse variaablusuuringu eesmärkidel kogutud ainestikku. Esimeses näites on uurija eesmärk analüüsida kakskeelse rääkija koodivahetuse avaldumisvormide struktuuri eestisoome koodivahetuse põhjal (uurimuse aluseks on kvalitatiivne meetod). Näeme, et üleminek eesti keelelt soome keelele on hetkeline, hõlmates ühesõnaliste võõrkoodi 
substantiivide morfoloogilist sisestamist vestluse põhikoodi vastavalt eesti keele morfosüntaktilisele struktuurile. Kuigi esitatud näites toimub üleminek soome keelele ühe lause sees kolm korda, on koodivahetuse esinemissagedus tervikuna keelejuhi idiolektis minimaalne. Koodivahetuse keeleainestiku kogumine on töömahukam ja pikemaajalisem protsess.

(3) INF: Näiteks kui ma helistasin sinna (.) verotoimistosse:ja küsisin verokortti endale:ja siss uut verokortti ja kontrollis mu andmeid:ja küsis kodakondsuse ja kui ma olin või nime järgi või kodakondsuse järgi ilmselt vaatas et pole soomlane ja siss hakkas kohe pakkuma ee ingliskeelset verokortti.

(näide autori erakogust)

Teine näide (4a) kirjeldab kahe võru keelealal elava keelejuhi argivestlust; (4b) on näite eestikeelne tõlge. Kvantitatiivset meetodit rakendaval uurijal on võimalik ka lühikese vestluse põhjal saada esimesed andmed näiteks vokaalharmoonia kasutamise kohta.

(4a) JR: kệnói om nî rašsę ((KP-le)) koGu a aèg kẹik valuttaB

AK: kui vanęmBas̀ sát

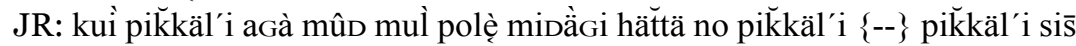
olęšsi \{--\} koGò aìg piät likkuma

KP: $\mathrm{mhmh}$

JR: vīmäne käik vaija tettä käümä piät

JR ((KP-le)): ei vẹi vôDišse magàma jầDa

$\mathrm{KP}: \mathrm{mhmh}$

(4b) JR: 'kõndida on nii raske ((KP-le)) kogu aeg kõik valutab’

AK: 'kui vanemaks saad'

JR: 'kui pikali aga muud mul pole midagi häda no pikali \{--\} pikali siis oleks

$\{--\}$ kogu aeg pead liikuma'

KP: 'mhmh'

JR: 'viimane käik vaja teha käima pead'

JR ((KP-le)): 'ei või voodisse magama jääda'

KP: 'mhmh'

(näide Mets, Praakli 2007: 814-815)

Vaatluse all olevate keeleilmingute esinemissageduse põhjal võib järeldada, et kvantitatiivsete variaablusuuringute puhul on intervjuumeetodi kasutamine õigustatud. Kuigi uurimused kinnitavad (nt Gardner-Chloros 1991, Sarhimaa 1999, Verschik 2008) koodivahetuse eri funktsioonide ning keeleilmingu mitmetahulisuse avaldumist ennekõike argivestlustes, ei ole koodivahetusvormide minimaalsest esinemissagedusest hoolimata põhjust kvalitatiivsetes uurimustes intervjuumeetodi rakendamist välistada, küll aga tuleb arvestada tunduvalt töömahukama ning aeganõudva protsessiga, et kogutud ainestik võimaldaks täita uurimiseesmärgid. 


\section{Intervjueerija keeleoskus ja keelekasutus}

Suulise keeleainestiku kogumisel ei ole tähtsusetu ka intervjueerija keeleoskus. Mitmekeelsuse uuringute puhul võimaldab uurija keeleoskus rakendada samu keelelisi võimalusi, mis on keelejuhilgi (nt koodivahetus, laensõnade kasutamine jne). Intervjuunäide (5) iseloomustab intervjueerija teadlikult algatatud soome keele kasutust. Keelejuht reageerib intervjueerija algatusele sõna kordamisega edasistes voorudes, mida võib tõlgendada ka vestluspartneri kõne loomuliku kordamisena või kõne kohandamisena vastavalt kaaskõnelejale. Vestluse eesmärkidest lähtudes võib aga soome keele kasutust tõlgendada ka teadliku katsega mõjutada keelejuhi keelekasutust. Keelelisse manipuleerimisse suhtutakse keeleainestiku kogumises erinevalt (vt nt Codó 2008, Milroy, Gordon 2003). Tihtipeale ei olegi võimalik tuvastada selget piiri, kust algab keeleline manipuleerimine, millal on tegemist rollisuhete muutumisega, millal on intervjuust saanud argivestlus, mis mõjutab automaatselt nii intervjueerija kui ka keelejuhi keelekasutust.

(5) KP: aga kas on võimalik niimoodi öelda, et=et et kui on tegemist eestisoome soome segaperega, et=et siis pere keeleks kujuneb kujuneb soome keel võivõi see ei pida ei=ei pea paika?

EV: no see ei see siis alati pea paika.

KP: [alati]

EV: [ei pea paika]

(näide autori erakogust)

Ka järgmisesse näitesse (6) tuleb suhtuda kriitiliselt. Intervjueerija ja keelejuht vestlevad Soome koolisüsteemi teemadel. Intervjueerija esitab keelejuhile küsimuse õpilase emakeele ja soome keele õppeainete kohta, kasutades õppeainete nimetusi soome keeles. Keelejuht vastab intervjueerija küsimusele soomekeelseid termineid kasutades:

(6) KP: aga need õppeained, üks ongi siis see oppilaan äidinkieli ja teine on siis on see suomi toisena kielenä?

INF: meil on küll suomi äidinkielenä ((naerab))

KP: ahah ((naerab))

(näide autori erakogust)

\section{Intervjuu planeerimine ja keelejuhtide leidmine}

Edukas intervjueerimine eeldab hoolikat läbi mõeldud strateegiat ning tegevuse planeerimist. Enne tegeliku ainestiku kogumist on soovitatav läbi viia eelintervjuud, mis annavad uurijale vajalikku teavet intervjuude struktuuri ning valitud teemade sobivuse kohta. Mida rohkem õnnestub uurijal intervjuu käiku n-ö läbi mängida, seda paremad tulemused andmekogumisel saadakse.

Eva Codó (2008: 168) esitab (eduka) intervjueerimise põhinõuded: 1) enne andmete kogumist tuleb hinnata intervjuu teostatavust ning sobivust; 2) uurija peab olema teadlik kultuurispetsiifilistest piirangutest (kellelt, mida ja millal küsida); 3) mida otsesem intervjuu, seda altimad on keelejuhid laskuma detailidesse; 4) intervjueerija peab vältima jah- ja ei-vastuseid eeldavaid küsimusi ning keelejuhi 
vastuste suunamist; 5) erinevad küsimuste formaadid ja tüübid muudavad intervjuu vähem monotoonseks; 6) küsimused peavad olema lühikesed, lihtsalt mõistetavad ja ühetähenduslikud.

Intervjuu optimaalne pikkus on 60-90 minutit, W. Labovi hinnangul üks kuni kaks tundi igalt rääkijalt (Milroy, Gordon 2003: 61). Lühemate intervjuude puhul osutub uurimisainestiku hankimine problemaatiliseks, kuid siinkohal tuleb arvestada ka uuritavate keelejoonte eripäraga. Kui näiteks aktsendi uurimisel piisab ka lühikese kestusega intervjuudest, siis kakskeelse keelekasutuse analüüsimine eeldab ühelt keelejuhilt vähemalt ühe tunni pikkust ning korduvaid, eri situatsioonides tehtud lindistusi.

Läbi tuleb mõelda ka intervjuude temaatiline ülesehitus. Kuigi näiteks teemaintervjuud ei eelda küsimuste loogilist järgnevust, tuleb uurijal iga intervjuu strateegia ning ülesehitus läbi mõelda. Arukas oleks intervjuuteemad struktureerida temaatiliselt lähedaste, võrgustiku moodustavate moodulitena, see võimaldab sujuvat ning loogilist üleminekut ning tagasipöördumist ühelt teemalt teisele.

Sotsiolingvistika tunneb erinevaid keelejuhtide leidmise meetodeid. Efektiivseimaks keelejuhtide leidmise meetodiks peetakse nn lumepallimeetodit, inglise keeles network sampling või snowballmethod (lähemalt Milroy, Gordon 2003). Lumepallimeetodi puhul on keelejuhtide valiku aluseks teiste keelejuhtide soovitused ja nende sotsiaalsed kontaktid. Lumepallimeetodit kasutades on uurijal võimalik siseneda keelejuhtide võrgustikesse, mis annab intervjueerijale keelejuhtide kogukonnas teise staatuse (intervjueerija läheneb uuele keelejuhile mitte enam tundmatu isikuna, vaid n-ö sõbra sõbra rollis), võimaldades erinevalt võrgustikku mittekuuluvast intervjueerijast hankida vabamas vormis keeleainestikku (Sarhimaa 1999: 81, Milroy 1987: 53). Kui uurija kuulub keelejuhtidega samasse rühma, saadakse keelematerjali kogumises paremad tulemused, kuna intervjueerija on üks rühma tegevuses osalejatest (Suojanen 1982: 18). Artikli autori keeleainestike kogumiste kogemustele tuginevalt võib lumepallimeetodi abil sobivate keelejuhtide leidmises suhteliselt kindel olla, kuna üldjuhul soovitatakse uuteks keelejuhtideks inimesi, keda soovitaja (vahendaja) hästi tunneb ning kelle iseloomuomadusi ja keelelist käitumist hinnata osatakse. Vahendajate kasutamine loob keelejuhile ka parema ettekujutuse intervjuu käigust. Ühtlasi on keelejuhil olemas informatsioon nii intervjueerija, uurimuse kui esitatavate küsimuste kohta, see lihtsustab tunduvalt intervjuu toimumist.

Keelejuhi või potentsiaalse keelejuhikandidaadi tundmine ja tema soovitamine uurijale ei garanteeri inimese tegelikku sobivust. Keelejuhtide valik eeldab paljude faktoritega arvestamist (lähemalt Vaux, Cooper 1999: 7-9). Universaalset hea keelejuhi kriteeriumit ei ole olemas, keelejuhtide sobivuskriteeriumid on alati uurimuseesmärkide põhised ehk töötatud välja konkreetse uurimuse jaoks. Keelejuhi sobivus moodustub eri komponentidest, milles ühinevad uurija ja intervjueeritava iseloomujooned ning käitumismallid, mida omakorda mõjutavad vestlussituatsioon, vestluse eesmärgid ning mõlema osapoole motiveeritus. Mõned keelejuhid (inimtüübid) on intervjuuks alati sobivamad kui teised. 


\section{Intervjueerija ja intervjueeritava suhe}

Intervjuud ei saa pidada ühepoolseks ainestiku kogumiseks, vaid intervjueerija ja intervjueeritava vahelises dialoogis sündinud ainestikuks, mille kujunemine sõltub nendevahelistest suhtest (Kokkonen, Pyykkönen 2007). Pihla Vuorinen nimetab uurimisprotsessi erinevate kohtumiste sarjaks, mis mõjub ühel või teisel viisil kõiki uurimuse osapooli (Vuorinen 2001: 243).

Keeleainestiku kogumisel saavutab paremad tulemused uurija, kes on ise uuritava rühma liige või rühmaga lähedalt seotud. Seega peaks lingvistilist uurimust tegev isik vähemalt mingil määral kuuluma uuritavasse kogukonda või vähemalt tundma kogukonna suhtlusnorme (Kunnas 2007: 35). Sotsiolingvistikas peetakse mis tahes uurimisainestiku kogumisel ideaalseimaks isikuks uuritava rühma aktsepteeritud või kogukonnaga lähedaselt seotud inimest. Eriti oluliseks peetakse seda suuliste keeleainestike kogumisel: kui uurija kuulub keelejuhtidega samasse rühma, saadakse keelematerjali kogumises paremad tulemused, kuna intervjueerija on üks rühma tegevuses osalejatest (Suojanen 1982: 18; samal teemal ka Lappalainen 2004: 25, Kunnas 2007: 35, Codó 2008: 159-160). Hoolimata kriitikast uurija osalemise kohta keelejuhtide igapäevases tegevuses (uurija mõjutab keelekasutust, ei suuda olla objektiivne), on näiteks Hanna Lappalaise hinnangul tema kogutud ainestik väga loomulik just sel põhjusel, et ta on uurijana vastavates situatsioonides lugematuid kordi viibinud (Lappalainen 2004: 26). Samas ei ole uurija rühma osalise liikme staatus kindlasti probleemivaba. Kahe rolli tasakaalustamisel tekivad uued probleemid, millest üks on kahene identiteet. Uurija asub samaaegselt nii uuritava rühma sees kui ka väljas, sageli on ta korraga kahel pool (Vuorinen 2001: 238).

Rollisuhete muutumine on kahtlemata üks olulisemaid keeleainestiku kujunemist mõjutavaid tegureid. Näide (7) kirjeldab mõlema vestleja jaoks ootamatut vestlussituatsiooni, kus ühest vestluspartnerist saab intervjuu läbiviija. Rollimuutus on ootamatu mõlema jaoks. Intervjuu alguses on täheldatav intervjueerija ja intervjueeritava ebakindlus lause formuleerimises, küsimuste esitamises ja nendele vastamises. Vestlejad kohanevad uue situatsiooniga suhteliselt kiiresti, kuid vestlust jääb saatma situatsiooni ametlikkus ning argivestlustega võrreldes erinevad käitumis- ja suhtlusmallid.

(7) KP: et teadsid=sa sakslasi enne kui sa Saksamaale kolisid?

INF: ee (.) einoh ma teadsin muidugi et sakslased on olemas (.) äh jah (.) raamatutest $=$ ja (.) kirjanikke (.) jaja seriaalidest $=\mathrm{ja}(($ naerab))

KP: ei: ma mõtlesin et et oli sul omal kokkupuuteid olnud (.) varem (..) elades Eestis?

(näide Praakli, Warnecke 2005: 8)

Intervjueerimise teel keeleainestikku koguv uurija seisab silmitsi intervjuu situatsioonilisusega. See, milliseks ainestik kujuneb, ei ole täna samasugune nagu homme või isegi tunni aja pärast. Tähendusetu ei ole loomulikult ka see, kus ja kuidas ainestik tekib ja mis toimub enne intervjuud (Marttila 2007). Tõenäoliselt on iga isikliku keeleainestikuga töötav uurija tundnud piinlikkust ja ebakindlust nii keelejuhtidega kontakteerumise kui ka lindistatud materjali läbikuulamise ning litereerimise ajal ning (osalisest) rühma liikme staatusest tulenevalt mõelnud rollide - uurija vs. rühma liige - segunemise ja põimumise ning piiride ületamise peale. Keelejuhtide 
tundmine ning nendega kohtumine ka väljaspool intervjuusituatsiooni lihtsustab kahtlemata keeleainestiku kogumist, kuid osutub problemaatiliseks kohanemise tõttu uute rollisuhetega, kus ühest osapoolest saab uurija, teisest uuritav. Seda on käsitlenud näiteks Pihla Vuorinen (2001), kes peatub probleemidel, nagu eraelu ning uurimistöö põimumine, uurijale lähedalseisvate inimeste rakendamine keelejuhtidena, jagatud kogemuste ning ühise mineviku mõju uurimisainestiku kogumisele, aga ka keelejuhtide ja intervjueeritava ootused teineteise suhtes ning intervjueeritava suhtumine keelejuhtidesse. P. Vuorinen (2001: 238-243) esitab mõned küsimused, millega puutub ilmselt kokku iga empiirilise uurimisainestikuga tegelev uurija: mida pakub keelejuhile osalemine uurimisprotsessis? Kas ja kuidas muutub keelejuhi suhtumine uuritavatesse? Kas uurija mõtleb keelejuhtidest kui ainult "oma materjalist"? Kas uurija lähedased (keelejuhid) peavad uurijat pidevalt jälgivaks kaaslaseks?

\section{Keeleainestiku esinduslikkus}

Keeleainestiku kogumise universaalsed probleemid on ainestiku maht (kvantiteet), laad (kvaliteet) ning esinduslikkus. Mis tahes uurimuse aluseks on hästi kogutud ainestik, mille suurus ning laad võimaldavad uurimust teostada ning püstitatud eesmärkidele vastavalt uurimisprobleemi lahendada. Ideaalne keeleainestik peaks esindama uuritavat kogukonda maksimaalselt, koosnema erinevatelt keelejuhtidelt kogutud keelematerjalist ning kirjeldama mõlemast soost, erineva sotsiaalse tausta ja vanusega rääkijate keelelist käitumist (Milroy 1987: 21).

Iga keeleainestiku kogumisega tegelev uurija esitab endale varem või hiljem küsimuse, kui suur peab olema keelejuhtide arv ning kas ainestik on esinduslik. Väikese rühma puhul osutub probleemiks tulemuste paigutamine laiemasse lingvistilisse konteksti, sest ühe rühma keeleline käitumine ei esinda kogukonda tervikuna (Lappalainen 2004: 17, Milroy 1989: 19, Milroy 1987: 38). Paraku ei ole keelejuhtide arvu eelnev kindlaksmääramine kvalitatiivse uurimuse puhul võimalik ega mõttekas. Keelejuhtide lõplik arv kujuneb töö käigus, vastavalt kogutud materjali hulgale ja laadile. Soome keeleteadlane Hanna Lappalainen (2004: 16) on seisukohal, et kui eesmärgiks on seatud indiviiditasandi keeleanalüüs, ei tohi uuritavate arvu ning ainestikku eriti suureks paisutada. Samal seisukohal on veel mitmed uurijad, rõhutades, et valimi täpne suurus ei ole keelelistel eesmärkidel nõutav: tähtis ei ole mitte see, et ainestikud vastaksid rangetele statistilise representatiivsuse nõuetele, vaid see, et kogutaks piisav hulk keelelist materjali, mis võimaldaks täita uurimiseesmärgid (Sarhimaa 1999: 100; Milroy 1989: 21-25).

Keelejuhtide käitumist mõjutavaks teguriks võib osutuda ka uurimuse eesmärkide detailne avaldamine. Sotsiolingvistid on lahendanud eesmärkide avaldamise erineval viisil. P. Nuolijärvi on seisukohal, et intervjuude eesmärk tuleks umbkaudselt lahti seletada ning öelda keelejuhtidele, et uurimus on mingil määral keelekasutusega seotud (Nuolijärvi 1986). A. Sarhimaa (1999) ei avaldanud keelejuhtidele uurimuse tegelikku teemat, et mitte suurendada uurija mõju, teatades, et uurimus käsitleb karjalaste igapäevaelu, kuid küsimused puudutavad ka keeleprobleeme.

Uurimuse eesmärkide avaldamine keelejuhile on keeleainestiku kogumisel üks uurija eetika põhialuseid. Uurijal tuleb ainestiku kogumisel lähtuda kolmest aspektist: intervjueeritav peab teadma intervjuu sisu ja eesmärke (keeleainestike puhul 
piisab, kui intervjueeritav teab, et uuritakse tema keelt, üksikasjalikesse selgitustesse laskumata) ning uurija peab garanteerima keelejuhi ja keeleainestiku anonüümsuse. On iseenesest mõistetav, et suulise keeleainestikuga töötamine eeldab uuritavatelt kirjaliku nõusoleku saamist, uurija peab tagama kõikide keelejuhtide anonüümsuse. Kõik kogutud materjalid jäävad üldjuhul uurija valdusse (kui ei ole teisiti kokku lepitud) ning neid kasutatakse ainult uurimiseesmärkidel.

\section{Kokkuvõte}

Artiklis on käsitletud intervjuumeetodi rakendamist keeleandmete kogumises. Peatutud on erinevatel ainestike tüüpidel, kirjeldatakse keeleainestiku kujunemise protsessi ning seda mõjutavaid tegureid.

Vaatluse all olnud intervjuuainestike kogumise eri aspektid kirjeldavad meetodi vastandlikke tahke. Ühelt poolt on intervjueerimine süstemaatiline, paindlik ning suhteliselt lihtsalt rakendatav meetod, mis võimaldab uurijal keeleainestiku kogumisel kiiresti eesmärgile jõuda, teisest küljest ei garanteeri ka parimal võimalikul viisil planeeritud ning struktureeritud intervjuu loodetud tulemust, kui uurija ei arvesta intervjueerimisega lahutamatult kaasnevaid kõrvalnähte, nagu vaatleja paradoks, vastastikune mõjutamine, keelelise käitumise (ala)teadlik muutumine, mis otsese tulemusena avaldub rääkija suulises keelekasutuses. Mis tahes intervjuuainestik kujuneb alati mõlema osapoole koostöö tulemusena, koostööd suunavad omakorda vestlussituatsioon ning seda mõjutavad tegurid. Mitmed intervjuumeetodiga kaasnevad probleemid on lahendatavad uurimuse planeerimise varases etapis. Uurija otsus kvantitatiivse või kvalitatiivse uurimismeetodi rakendamise kohta aitab mitmeid probleeme vältida ning intervjuu vastavalt ühe või teise meetodi vajadustele ning tingimustele ette valmistada.

Ükskõik millisel meetodil keeleainestik ka kogutud ei oleks, isiklikult kogutud ainestik annab igale uurijale selle analüüsimisel paremad eelised kui võõra ainestikuga töötamine, kus paratamatult palju olulist teavet, nagu vestlussituatsioon, keelejuhi käitumine, keelekasutuse muutumine jne, uurijal kirjeldamata võib jääda.

\section{Transkriptsioonimärgid}

$=\quad$ otsarääkimine (kahe üksuse vahel ei ole vaikust)

[ pealerääkimise algus

] pealerääkimise lõpp

(.) mikropaus: 0.2 sekundit või lühem

.jaa sissehingamise ajal hääldatud sõna

(( )) transkribeerija kommentaar

$\{-\} \quad$ transkribeerimatu segment

: hääliku venitamine

(o.8) mõõdetud paus kümnendiksekundites 


\section{Viidatud kirjandus}

Codó, Eva 2008. Interviews and questionnaires. - Li Wei, Melissa G. Moyer (Eds.). The Blackwell Guide to Research Methods in Bilingualism and Multilingualism. Oxford: Blackwell Publishing, 158-177.

Eskola, Jari; Suoranta, Juha 2003. Johdatus laadulliseen tutkimukseen. Tampere: Vastapaino.

Gardner-Chloros, Penelope 1991. Language Selection and Switching in Strasbourg. Oxford Studies in Language Contact. Oxford: Clarendon Press.

Halmari, Helena 1997. Government and Codeswitching: Explaining American Finnish Codeswitching. Studies in Bilingualism 12. Amsterdam: John Benjamins.

Hennoste, Tiit; Lindström, Liina; Rääbis, Andriela; Toomet, Piret; Vellerind, Riina 2000. Eesti suulise kõne korpus ja mõnede allkeelte võrdluse katse. - Tiit Hennoste (toim.). Arvutuslingvistikalt inimesele. Tartu Ülikooli üldkeeleteaduse õppetooli toimetised 1. Tartu: TÜ Kirjastus, 245-285.

Hirsjärvi, Sirkka; Hurme, Helena 1980. Teemahaastattelu. Helsinki: Gaudeamus.

Hirsjärvi, Sirkka; Pirkko, Remes; Sajavaara, Paula 2005. Uuri ja kirjuta. Tallinn: Medicina.

Kokkonen, Lotta; Pyykkönen, Miikka 2007. Tutkija, tukija vai ystävä? Haastattelijan ja haastateltavan suhde maahanmuuttajuuden tutkimuksessa. - III kulttuurintutkimuksen päivät. Joensuun yliopisto, 14.-15.12.2007. http://www.jyu.fi/kultut/III_kt_paivat_haastattelu_abstraktit.html (20.04.2008).

Kunnas, Niina 2007. Miten muuttuu runokylien kieli. Reaaliaikatutkimus jälkitavujen A-loppuisten vokaalijonojen variaatiosta vienalaismurteissa. Oulun yliopiston suomen kielen, informaatiotutkimuksen ja logopedian laitos. Oulu: Oulun yliopisto.

Labov, William 1972. Sociolinguistic Patterns. Philadelphia: University of Pennsylvania Press.

Lappalainen, Hanna 2004. Variaatio ja sen funktiot: erään sosiaalisen verkoston jäsenten kielellisen variaation ja vuorovaikutuksen tarkastelua. Suomalaisen kirjallisuuden seuran toimituksia 964. Helsinki: Suomalaisen kirjallisuuden seura.

Lehtonen, Heini 2004. Maahanmuuttajataustaisten helsinkiläisnuorten puheen variaatio ja monikielisyys. Pro gradu-tutkielma. Helsingin yliopiston suomen kielen laitos.

Lindström, Liina 2001. Eesti murrete korpuse iseloomustus argivestlustega võrrelduna. Reet Kasik (toim.). Keele kannul. Pühendusteos Mati Erelti 6o. sünnipäevaks 12. märtsil 2001. Tartu Ülikooli eesti keele õppetooli toimetised 17. Tartu: TÜ Kirjastus, 212-222.

Loog, Mai 1992. Nende sõned, sõnad: uurimus eriealiste tüdrukute ja poiste kõnekeelest. Opera fennistica \& linguistica 6. Tampere: Tampereen yliopiston suomen kielen ja yleisen kielitieteen laitos.

Marttila, Annamaria 2007. Aineiston rakentumisen tilanteisuus. http://www.jyu.fi/kultut/ III_kt_paivat_haastattelu_abstraktit.html (20.04.2008).

Mets, Mari; Praakli, Kristiina 2007. Suhtlusvõrgustikud võrukeste keelelise käitumise tõlgendajaina. - Keel ja Kirjandus, 10, 799-817.

Milroy, Lesley 1987. Language and Social Networks. Language in Society 2. Oxford: Blackwell.

Milroy, Lesley 1989. Observing and Analysing Natural Language. Oxford: Blackwell.

Milroy, Lesley; Gordon, Matthew 2003. Sociolinguistics. Methods and Interpretations. Malden, MA: Blackwell Publishing.

Neuman, Lawrence William 2003. Social Research Methods. Qualitative and Quantitative Approaches. Fifth edition. Boston: Allyn \& Bacon.

Nuolijärvi, Pirkko 1986. Kolmannen sukupolven kieli: Helsinkiin muuttaneiden suurten ikäluokkien eteläpohjalaisten ja pohjoissavolaisten kielellinen sopeutuminen. Suomalaisen kirjallisuuden seuran toimituksia 436. Helsinki: Suomalaisen kirjallisuuden seura. 
Praakli, Kristiina; Warnecke, Irmela 2005. Zweisprachiges Interview mit einer in Deutschland lebenden estnischen Muttersprachlerin. Hausarbeit. Johannes Gutenberg-Universität Mainz, Sprachen Nordeuropas und des Baltikums.

Riionheimo, Helka 2007. Muutoksen monet juuret: oman ja vieraan risteytyminen Viron inkerinsuomalaisten imperfektinmuodostuksessa. Suomalaisen kirjallisuuden seuran toimituksia 1107. Helsinki: Suomalaisen kirjallisuuden seura.

Sarhimaa, Anneli 1999. Syntactic Transfer, Contact-induced Change, and the Evolution of Bilingual Mixed Codes: Focus on Karelian-Russian Language Alternation. Studia fennica. Linguistica 9. Helsinki: Finnish Literature Society.

Schlobinski, Peter 1996. Empirische Sprachwissenschaft. Opladen: Westdeutscher Verlag.

Suojanen, Matti K. 1982. Sosiolingvistiikan näkymiä. Kielitieteen peruskirjallisuutta. Helsinki: Gaudeamus.

Wardhaugh, Ronald 2002. An Introduction to Sociolinguistics. Massachusetts: Blackwell Publishers.

Vaux, Bert; Cooper, Justin 1999. Introduction to Linguistic Field Methods. LINCOM Coursebooks in Linguistics 01. Muenchen: Lincom Europa.

Verschik, Anna 2008. Emerging Bilingual Speech: From Monolingualism to Code-Copying. London, New York: Continuum Intl Pub Group.

Vuorinen, Pihla 2001. Oma pere ja tuttavate ringis tehtava uurimistöö valguse- ja varjupooled. - Tiiu Jaago (toim.). Pärimuslik ajalugu. Tartu: Eesti Kirjandusmuuseum, 235-244.

Kristiina Praakli (Tartu Ülikool) teaduslike huvide hulka kuuluvad kontaktlingvistika, mitmekeelsus (koodivahetus) ning suhtlusvõrgustike uuringud.

kristiina.praakli@ut.ee 


\section{INTERVIEW AS A METHOD TO COLLECT LINGUISTIC DATA}

\section{Kristiina Praakli}

University of Tartu

The article expands upon applying the method of interviewing in collecting language data. The article distinguishes between several types of linguistic data, describes the collecting of language material as a process and various factors influencing that process.

The article describes different aspects of collecting material by way of interviews, revealing some contrary aspects of the interview as a method. On the one hand the interviewing process is systematic, flexible, and as a method, it can be applied quite easily, permitting the investigator to reach its purpose quickly; on the other hand there is no guarantee for a perfectly planned and structured interview to meet its purpose if the interviewer does not take into consideration the possible side-effects, for example the observer's paradox, mutual influence, (sub)conscious changes in the language behaviour, which appear in the oral language use of the speaker. Whatever the material resulting from an interview it takes shape as a result of collaboration between two parties, which, in turn, is coordinated by the situation of the conversation and its aspects.

Keywords: oral language, language data, language behaviour, sociolinguistics, empirical material, Estonian 